\title{
The Wall Composition of Micrococci
}

\author{
By J. BADDILEY, J. H. BROCK, A. L. DAVISON AND \\ MARGARET D. PARTRIDGE \\ Microbiological Chemistry Research Laboratory, Department of Organic \\ Chemistry, The University, Newcastle upon Tyne, NE I 7 RU
}

(Accepted for publication 31 July 1968)

\begin{abstract}
SUMMARY
The distribution of teichoic acids and extractable polysaccharides in the walls of the various micrococci examined did not show a direct correlation with the conventional systematic classification of these organisms. Three main groups were distinguished: in one group (A) ribitol teichoic acids containing glucosamine were found; in a second group (B) glycerol teichoic acids with a variety of sugar substituents were found; in a third group (C) wall teichoic acids were absent but polysaccharides were extracted from the walls. The third group (C) represents the species Micrococcus conglomeratus, and the lack of order in the structure of the extractable polysaccharides supports previous criticism of the validity of this species.
\end{abstract}

\section{INTRODUCTION}

The cell walls of staphylococci contain distinct teichoic acids (Davison \& Baddiley, 1963). In the species Staphylococcus aureus the polymer is of the ribitol type with $\alpha$ and $\beta-N$-acetylglucosamine residues (Baddiley, Buchanan, RajBhandary \& Sanderson, 1962 ), whereas in the species $S$. epidermidis it is of the glycerol type with glucose residues (Davison \& Baddiley, 1964). Immunochemical specificity of these teichoic acids is related to differences in glycosidic configuration (Davison, Baddiley, Hofstad, Losnegard \& Oeding, I964; Nathenson, Ishimoto, Anderson \& Strominger, I966; Oeding, Myklestad \& Davison, 1967). In strains of S. lactis no similar homogeneity in type of teichoic acid is found, and one strain (13) contains a polymer of glycerol phosphate and $\mathrm{N}$-acetylglucosamine I-phosphate, that has been extensively studied (Archibald, Baddiley \& Button, 1965; Button, Archibald \& Baddiley, 1966; Blumsom, Douglas \& Baddiley, I966; Archibald, Baddiley \& Button, I968; Baddiley, Blumsom \& Douglas, I968). The majority of strains of $S$. lactis are micrococci (Baird-Parker, I965). The present paper investigates further their cell-wall composition.

\section{METHODS}

Organisms and preparation of walls. Cultures were obtained from the National Collection of Industrial Bacteria, the National Collection of Type Cultures, the Czechoslovak Collection of Micro-organisms and from Drs A. C. Baird-Parker, R. G. Mitchell and M. S. Pohja. All the bacteria studied were Gram-positive catalasepositive cocci. Oxidation of glucose, mannitol and lactose was examined by the recommended method (Subcommittee, 1965). All strains of Micrococcus conglomeratus 
oxidized glucose but not mannitol or lactose, with the exception of NCIB 2677 , which did not oxidize glucose.

Walls were prepared by mechanical disintegration of cocci with Ballotini beads in a shaker head or a Braun homogenizer. Teichoic acids or polysaccharides were extracted with cold dilute trichloroacetic acid as described previously (Davison \& Baddiley, 1963; Davison, 1968). Teichoic acids and polysaccharides were identified by paper chromatography of hydrolysates (Armstrong, et al. 1958; Baddiley et al. 1962; Davison \& Baddiley, 1963).

Analyses. For the polysaccharides from Micrococcus species 740,836 and 2677 , glucose was determined after hydrolysis in $2 \mathrm{~N}-\mathrm{HCl}$ for $\mathrm{I} \mathrm{hr}$ at $100^{\circ}$ by the Glucostat reagent (Worthington Chemical Corporation, New Jersey, U.S.A.), total hexose by the phenol + sulphuric acid method of Dubois et al. (1956), and total hexosamine by the method of Rosen (I957). For the teichoic acid from Micrococcus species 8, which contained alanine, galactosamine and glucosamine were determined in the Technicon autoanalyser, glucose by the method of Dubois et al. (1956), and phosphorus by the method of Chen, Toribara \& Warner (1956).

\section{RESULTS}

Group $A$. Walls of these strains contained ribitol teichoic acid with $N$-acetylglucosamine residues; traces of glucose were detected in the preparations. The organisms were: Micrococcus species 234 and 238 (Pohja, 1960); 34 and 51877 (Alder, Brown \& Mitchell, I966); NCIB 8609; NCTC I89. Ribitol and its glucosaminide were detected after hydrolysis with alkali and then enzymic dephosphorylation of the teichoic acid from NCTC 189. This degradation procedure was not done on the other strains in this group.

Group $B$. Walls of these strains contained complex glycerol teichoic acids; some of the preparations contained both hexose and hexosamine residues. The organisms were: Micrococcus species 8 and 24 (Baird-Parker, I965); I3 (Davison, I968); NCIB 8I74. The teichoic acid preparation from Micrococcus species strain 8 had an optical rotation $+93.5^{\circ}$ (c. 0.4 water), and contained glucose, glucosamine and galactosamine in a molecular ratio total sugar to phosphate of 0.9: I. It was stable to hydrolysis by alkali, indicative of a fully glycosylated $\alpha$-linked polymer. Teichoic acid from strain 24 gave glycerol diphosphates, glucosamine and traces of ribitol derivatives on acid hydrolysis; a saccharinic acid was formed in alkali. This polymer is presumably similar to the polymer of glycerol phosphate and glucosamine I-phosphate in walls of Micrococcus species 13 (Archibald et al. 1968), but contains ribitol units. Teichoic acid from the strain NCIB 8I74 contained glucose, glucosamine, rhamnose and galactose. This polymer preparation is complex, as both teichoic acid and a polysaccharide were seen on paper electrophoresis ( $0.05 \mathrm{M}$-veronal+hydrochloric acid buffer $(\mathrm{pH}$ $8 \cdot 5$ ), voltage gradient $8.5 \mathrm{~V} / \mathrm{cm}$.).

Group $C$. Walls of these strains contained non-phosphorylated polysaccharides; no teichoic acids were detected. The organisms were: Micrococcus conglomeratus CCM, 825, 836, 740; NCIB 2677. Polysaccharide material from strain CCM 825 contained glucose, galactose and traces of glucosamine; that from СCM 836 contained galactose and glucosamine in a molecular ratio of $3: 1$. Strain CCM 740 and NCIB 2677 both contained polysaccharides of glucose, galactose and galactosamine. These differed structurally, with respective molecular proportions of sugars of $I: 2: I$ and $I: 3: 2$. 


\section{DISCUSSION}

In this study micrococci have been divided into three groups: in group A the walls contained ribitol teichoic acid with $N$-acetylglycosaminyl substituents; in group B they contained glycerol teichoic acids with a variety of carbohydrate substituents; in group $\mathrm{C}$ no teichoic acids were found in the walls but these contained polysaccharides with varying carbohydrate components. The physiological characteristics of the micrococci show little correspondence with the distribution of polymers in the walls. Thus, ribitol teichoic acids are wall components in some (group A) glucose-oxidizing acetoin-negative micrococci, whereas others (groups B, C) contain either glycerol teichoic acids or polysaccharides.

The nature of the wall polymers in some individual cases is noteworthy. Thus, Micrococcus species NCTC 189 (group A) contains a ribitol techoic acid in which several of the ribitol phosphate residues lack the usual $\mathrm{N}$-acetylglucosaminyl substituent; this differs markedly from strains of Staphylococcus aureus where such a substituent is probably present on each ribitol phosphate (Baddiley et al. 1962; Davison et al. 1964). The teichoic acid preparation from strain 8 (group B) contains glycerol phosphate residues, each of which must possess a glycosyl substituent since the polymer is stable towards alkali. The substituents are glucosamine, galactosamine (presumably both as $\mathrm{N}$-acetyl derivatives) and glucose; it is not yet known whether this strain contains a mixture of teichoic acids, or whether the three different glycosyl substituents occur on the same polymer chain. Strain 24 (group B) contains wall teichoic acid showing chemical similarities to the extensively studied strain 13, but the preparation gives, on acid and alkali hydrolysis, degradation products of ribitol in addition to glycerol. The strains of $M$. conglomeratus (group C) contain in their walls a heterogeneous collection of polysaccharides; strain CCM 825 possesses a polysaccharide of glucose and galactose, whereas that from strain CCM 836 contains galactose and glucosamine. A glucose-oxidizing strain CCM 740 and a strain NCIB 2677 that does not oxidize glucose both contain structurally different polysaccharides of glucose, galactose and galactosamine.

The validity of the species Micrococcus conglomeratus is questionable (Baird-Parker, 1965; Evans, 1965). It is significant that walls of highly pigmented cocci received as this species (group C) differ from the rest of the micrococci studied, in that they have polysaccharides but no wall teichoic acids. These cocci are weak glucose oxidizers (Mortensen \& Kocur, 1967) and may be representative of a group distinct from the predominantly non-pigmented more halotolerant cocci with teichoic acid.

Many glucose-oxidizing acetoin-negative micrococci are physiologically indistinguishable (Baird-Parker, 1965), and differences we have observed in the teichoic acid and polysaccharide composition of their cell walls may be of value in their delineation and in the establishment of the validity of reputed species.

We thank the Science Research Council for financial support and for the award of studentships (to J.H.B. and M.D.P.). 


\section{REFERENCES}

Alder, V. G., Brown, A. M. \& Mrtchell, R. G. (1966). The reactions of coagulase negative staphylococci and micrococci. J. appl. Bact. 29, 304.

Archibald, A. R., BadDIley, J. \& Button, D. (1965). A new kind of teichoic acid from the cell walls of a strain of Staphylococcus lactis. Biochem. J. 95, 8C.

ARChIBALD, A. R., BADDIEEY, J. \& Burton, D. (1968). The glycerol teichoic acid of walls of Staphylococcus lactis I3. Biochem. J. (in the Press.)

Armstrong, J. J., Baddiley, J., Buchanan, J. G., Carss, B. \& Greenberg, G. R. (I958). Isolation and structure of ribitol phosphate derivatives (teichoic acids) from bacterial cell walls. J. chem. Soc. p. 4344 .

Baddiley, J., Blumsom, N. L. \& Douglas, L. J. (1968). The biosynthesis of the wall teichoic acid in Staphylococcus lactis 13. Biochem. J. (in the Press.)

Baddiley, J., Buchanan, J. G., RajBhandary, U. L. \& Sanderson, A. R. (I962). Teichoic acid from walls of Staphylococcus aureus H. Biochem. J. 82, 439.

Batrd-PARKER, A.C. (I965). The classification of staphylococci and micrococci from world-wide sources. J. gen. Microbiol. 38, 363.

Blumsom, N. L., Douglas, L. J. \& Baddiley, J. (1966). The biosynthesis of the wall teichoic acid from a strain of Staphylococcus lactis. Biochem. J. 100, 26.

Button, D., ARChibald, A. R. \& BADDIIEY, J. (1966). The linkage between teichoic acid and glycosaminopeptide in the walls of a strain of Staphylococcus lactis. Biochem. J. 99, I I C.

Chen, P. S., Toribara, T. Y. \& Warner, H. (1956). Microdetermination of phosphorus. Analyt. Chem. 28, 1756.

DAvison, A. L. (1968). The characterization of a Micrococcus (Staphylococcus lactis) sp. 13 with an atypical teichoic acid in its wall. Biochem. J. (in the Press.)

Davison, A. L. \& BADDILEY, J. (I963). The distribution of teichoic acids in staphylococci. J. gen. Microbiol. 32, 271.

DAVISON, A. L. \& BADDILEY, J. (1964). Glycerol teichoic acids in walls of Staphylococcus epidermidis. Nature, Lond. 202, 874.

Davison, A. L., Baddiley, J., Hofstad, T., Losnegard, N. \& Oeding, P. (1964). Teichoic acids in walls of Staphylococci. Serological investigations on teichoic acids from walls of Staphylococci. Nature, Lond. 202, 872.

Dubois, M., Gilles, K. A., Hamilton, J. K., Rebers, P. A. \& Smith, F. (1956). Colorimetric method for determination of sugars and related compounds. Analyt. Chem. 28, 350.

Evans, J. B. (1965). Current views and problems relating to the taxonomy of the Micrococcaceae. Int. Bull. bact. Nomencl. 15 , III.

MoRTENSEN, N. \& KoCUR, M. (1967). Correlation of DNA base composition and acid formation from glucose of staphylococci and micrococci. Acta path. microbiol. scand. 69, 445.

NAthenson, S. G., Ishmoto, N., ANDerson, J. S. \& Strominger, J. L. (1966). Enzymatic synthesis and immunochemistry of $\alpha$ - and $\beta$ - $N$-acetylglucosaminylribitol linkages in teichoic acids from several strains of Staphylococcus aureus. J. biol. Chem. 24I, 65I.

Oeding, P., Myklestad, B. \& Davison, A. L. (I967). Serologic investigations on teichoic acids from the walls of Staphylococcus epidermidis and Micrococcus. Acta path. microbiol. Scand. 69, 458.

PoHJA, M. S. (1960). Micrococci in fermented meat products. Classification and description of I7I different strains. Suom. Maataloust. Seur. Julk, no. 96, I.

Rosen, A. (1957). A modified ninhydrin colorimetric analysis for amino acids. Arch. Biochem. Biophys. 67, 10.

SUBCOMMITTEE ON TAXONOMY OF STAPHYLOCOCCI AND MICROCOCCI (1965). Recommendations Int. Bull. bact. Nomencl. Taxon. 15, 109. 